\title{
FASTK wt Allele
}

National Cancer Institute

\section{Source}

National Cancer Institute. FASTK Wt Allele. NCI Thesaurus. Code C51201.

Human FAST K wild-type allele is located within 7q35 and is approximately 4 kb in length.

This allele, which encodes Fas-activated serine/threonine kinase protein, is involved in apoptotic inhibition via a mechanism mediated by the translational silencer TIA-1. 